Laporan Kasus

\title{
Twin to Twin Transfusion Syndrom
}

\author{
Yusrawati $^{1}$, Rika Effendy ${ }^{2}$
}

\begin{abstract}
Abstrak
Peningkatan mortalitas pada kembar monokorion disebabkan oleh adanya anastomosis vaskuler pada plasenta yang menyebabkan Twin to Twin Transfussion syndrome.Berikut laporan kasus yang ditangani di RS. DR. M. Djamil Padang. Kasus 1: Seorang pasien usia 28 tahun dengan diagnosa MP3 gravid preterm 33-34 minggu dengan Twin To Twin Transfusion Syndrom, Dari pemeriksaan USG didapatkan kesan: Gemelli, gravid 33-34 minggu dengan TTTS. Pasien diterminasi secara SCTPP. Bayi pertama lahir perempuan, dengan: BB: 1400 grams, PB: 44 cm, A / S: 8/9, Bayi ke II: perempuan, BB: 1000 grams, PB: 38 cm, A / S: 6/7, Hb janin I: 16,9 g/dl dan Hb janin II : 11,3 g/dl. Kedua bayi dirawat di bagian perinatology. Bayi pertama bertahan hidup dengan beberapa kelainan kongenital yaitu VSD dan Hemangioma Orbita. Bayi kedua meninggal pada usia 7 hari dengan susp. Sepsis. Hingga saat ini, bayi ini masih kontrol rutin ke poliklinik RS. DR. M. Djamil Padang. Kasus 2: Seorang pasien usia 31 tahun dengan diagnosa MP5 parturient aterm kala II dengan gemelli. Pasien melahirkan spontan. Bayi pertama lahir perempuan dengan: BB: 3200 grams, PB: 48cm, A / S: 8/9, Bayi ke II perempuan: BB: 2100 grams, PB: 44 cm, A / S: 7/8. Kadar Hb bayi I : $17,6 \mathrm{~g} / \mathrm{dl}$ dan bayi II: 14,1 g/dl. Plasenta lahir secara spontan lengkap 1 buah, berat $1150 \mathrm{gr}$, ukuran $20 \times 19 \times 3 \mathrm{~cm}$, panjang kedua tali pusat masing-masing $60 \mathrm{~cm}$, insersi paracentralis,Monokhorion-Monoamnion. Kesan: TTTS.
\end{abstract}

Kata kunci: twin to twin transfusion sindrom, ultrasonografi, monokorion

\begin{abstract}
Increased mortality in monochorionic fetus caused by vascular anastomosis in the placenta that causes Twin to Twin Transfusion Syndromes (TTTS). Reporting two cases experienced and taken care in our hospital. Case 1: a woman 28 years old was diagnosed with MP3 preterm pregnancy 33-34 weeks with Twin to Twin Transfusion Syndromes. Ultrasound impression: Gemelli gravid 33-34 weeks with TTTS. The patient was terminated by SCTPP. The first baby was female, born with: BW: 1400 grams, BL: $44 \mathrm{~cm}, A / S: 8 / 9$, the second baby: female, BW: 1000 grams, BL: $38 \mathrm{~cm}, A / \mathrm{S}: 6 / 7$ the first baby Hemoglobin was 16,9 g/dl and the second baby was 11,3 g/dl. The babies were treated in Perinatology, the first baby survive with some congenital abnormalities such as VSD and hemangioma in the orbita. The second baby died at the age of 7 days with suspected sepsis. To date the baby still has a routine medical checkup to RS. DR. M. Djamil Padang. Case2: a woman 31 years old with diagnose MP5 term parturient in second stage of labour with, gemelli. The babies were born spontaneously. The first baby: BW: $3200 \mathrm{gr}, \mathrm{BL}: 48 \mathrm{~cm}$, A/S: 8/9. The second baby: BW: $2100 \mathrm{gr}, \mathrm{BL}: 44 \mathrm{~cm}, \mathrm{~A} / \mathrm{S}$ : 7/8. Hemoglobin Concentration of the first baby: 17,6 g/dl and the second baby :11,4 g/dl. Placenta was born monochorion, diamnion.
\end{abstract}

Keywords:twin to twin transfusion syndrome, ultrasonography, monochorion

Affiliasi penulis : 1.Bagian Obgyn Fakultas Kedokteran Universitas Andalas, 2. PPDS Obgyn Fakultas Kedokteran Universitas Andalas Korespondensi :Yusrawati, email; dr_yusrawati@yahoo.com, telp: 08126633997; Rika Effendy, email: rika_effendy@yahoo.com, Telp: 081363135195

\section{Introduction}

Multiple pregnancy is a pregnancy with two or more fetus. Multiple pregnancy is a high risk pregnancy that reach $12 \%$ perinatal morbidity. Determination of zygote, Chorionicity, and amnionicity is essential for management of pregnancy. Increased mortality in monochorionic fetus caused by vascular anastomosis in the placenta that causes Twin to Twin Transfusion Syndromes (TTTS). Mothers with multiple pregnancy prone to preeclampsia, placental abruption, postnatal bleeding, trauma to the birth canal and other complications that may cause death. ${ }^{1,2}$

\section{Case Report}

Case 1

Reported a patient 28 years old, MP3 (Multy Parous 3) preterm pregnancy 33-34 weeks with TTTS who treated in obstetric department, DR. M.Djamil general hospital Padang on February 13, 2013. From the laboratories finding, obtained that Hemoglobin: $10.5 \mathrm{~g} / \mathrm{dl}$, leukocytes: 11.800/mm3, platelets: 231.000/mm3. From the Ultrasonography (USG) finding, Fetus I: female, BPD (Bipareatal Diameter): 84mm, AC (Abdominal Circumference): 290mm, FL (Femur Length): 63mm, HL (Humerus Length): 55mm, EFW (Estimated Fetal Weight): $2161 \mathrm{gr}$, SDAU (Systolic Diastolic Artery Umbilical): 1.80, polyhydramnion with AFI (Amniotic Fluid Index) single pocket 15.5 cmbladderuk $4.6 \times 3,0 \times 3,4 \mathrm{~cm}$. Fetus II: 
female, BPD: $72 \mathrm{~mm}$, AC: $251 \mathrm{~mm}$, FL: $60 \mathrm{~mm}$, HL: 51 $\mathrm{mm}$, EFW: $1317 \mathrm{~g}, 2.11 \mathrm{~S}$ DAU severe oligohydramnion, $\mathrm{AFI}<2 \mathrm{~cm}$, Stucktwin, emptybladder. Shown "T sign".

USG on Februari $14^{\text {th }}, 2013$

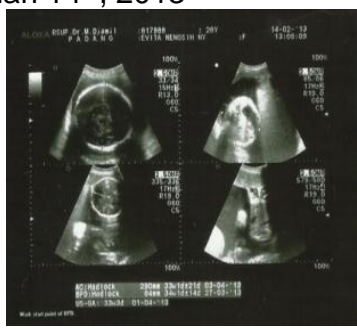

Figure 1. Discordance twin: Twins showing a marked difference in size (greater than $10 \%$ in weight) at birth. The condition is usually caused by over perfusion of one twin and under perfusion of the other. It is fairly common in identical twins but may also occur in dizygotic twins.

BPD (I): 84mm, BPD (II): $72 \mathrm{~mm}$

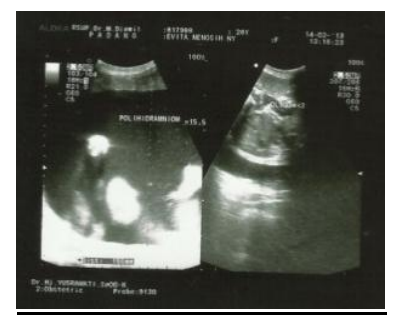

Figure 2. Polyhidramnion: excess of amniotic fluid, usually exceding $2000 \mathrm{~mL}$. AFI Single Pocket: 15,5 cm



Figure 3. Fetal bladder in donor twin is empty and fetal bladder in recipient twin is over distecy

The patient was treated at the obstetric room with Expectative management, for 7 days maintain ability maternal and fetal condition monitored closely. On February 20, 2013 an ultrasonography finding: Fetus I, Head presentation, fetal movement activity was good, Biometry: BPD: $84 \mathrm{~mm}$, AC: $276 \mathrm{~mm}$, FL: 65mm, HL: 58mm, EFW: 2161gr, SDAU: 2.66, AFI single pocket $12.2 \mathrm{~cm}$, bladders uk 2,0 x 2,9 x 2,8 cm. Fetus II, attached to the front wall of the uterus (fixed/stuck twin) severe oligohydramnion. Biometry BPD: $70 \mathrm{~mm}$, AC: $218 \mathrm{~mm}$, FL: $50 \mathrm{~mm}$, HL: $56 \mathrm{~mm}$. EFW: $1317 \mathrm{gr}$, SDAU: $3.00, \mathrm{AFI}<2 \mathrm{~cm}$, the bladder is empty. The placenta is embedded in the front of the corpus grade I-II. Impression: Gamely, gravid 34-35 weeks with TTTS. Advice: SC.

\section{USG on Februari $20^{\text {th }}, 2013$}

On February 20, 2013 at 15:10 pm, SCTPP was perform, baby I: was born female, BW (Birth Weight): $1400 \mathrm{~g}, \mathrm{BL}$ (Birth Length): $44 \mathrm{~cm}, \mathrm{~A} / \mathrm{S}: 8 / 9$, Baby II: was female with BW: $1000 \mathrm{~g}, \mathrm{BL}: 38 \mathrm{~cm}, \mathrm{~A} / \mathrm{S}$ (Apgar/Score): 6/7. Placental weight: $800 \mathrm{~g}$, size $25 \times 24 \times 3 \mathrm{~cm}$. Umbilical cord I length: $43 \mathrm{~cm}$ insertion: paracentalis, umbilical cord II length: $30 \mathrm{~cm}$, insertion velamentosa. There was a vascular anastomosis in the fetal placenta, impression: Monochorion-diamnion, with TTTS. Fetal I $\mathrm{Hb}: 16.9 \mathrm{~g} / \mathrm{dl}$ and fetal II Hb: 11.3. $\mathrm{gr} / \mathrm{dl}$ Both infants were treated at the Perinatology. The first baby was treated for 13 days. She had been survived with several congenital abnormalities, such as: VSD and haemangioma orbita. The second baby died at the age of 7 days due to septic.

Case 2:

Reported a patient, 31 years old was treated at the Obstetric room, Dr. M. Djamil General Hospital, Padang on January 26, 2014 with diagnosis: MP 5 second stage term parturient with Gamely. From the laboratory tests finding, obtained Hemoglobin: 10.7 g/dl, leukocytes: $5.300 / \mathrm{mm} 3$, platelets: $187.000 / \mathrm{mm} 3$. Ultrasound examination could not be performed because the patients in the second stage of labour. Baby I was born spontaneously, with BW: $3200 \mathrm{~g}$, BL: $48 \mathrm{~cm}, \mathrm{~A} / \mathrm{S}: 8 / 9$, female. Baby II: BW: $2100 \mathrm{~g}$, BL: 44 $\mathrm{cm}, \mathrm{A} / \mathrm{S}$ : $7 / 8$, female. The placenta was born spontaneously complete 1 piece, weight:1150 g, size: $20 \times 19 \times 3 \mathrm{~cm}$, both length of each cord $60 \mathrm{~cm}$, paracentralis insertion, and impression: Monochorion Diamnion. Hb babyl:17.6 g/dl, Hb baby II: $11.4 \mathrm{~g} / \mathrm{dl}, \mathrm{Ht}$ baby I: $53 \%$, Ht baby II: $43 \%$. Impression: TTTS. Until now,both babies are healthy and the congenital anomalies had not been found in both infants.

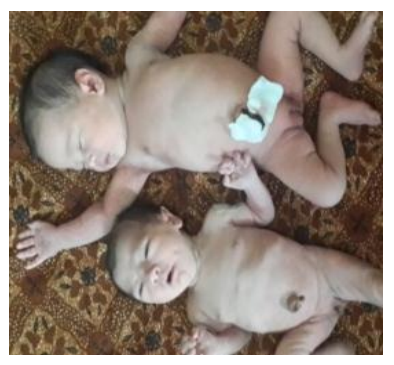

Figure 4. Baby in case 2 with Discordance Twin : difference in size greater than $10 \%$ in weight at birth

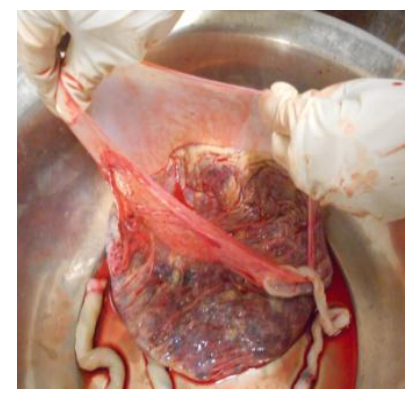

Figure 5. Monochorion Diamnion Placenta : a chorion with two amniotic sac 


\section{Discussion}

Approximately one-third gamely monozygotic has 2 twin monozygotik 2 amnions, 2 chorionics, and 2 placentas, sometimes 2 placentas into one piece. This situation is difficult to differentiate the dizygotic twin. The other two-thirds have one placenta, one chorionic and 1 or 2 amnions. ${ }^{3,4}$

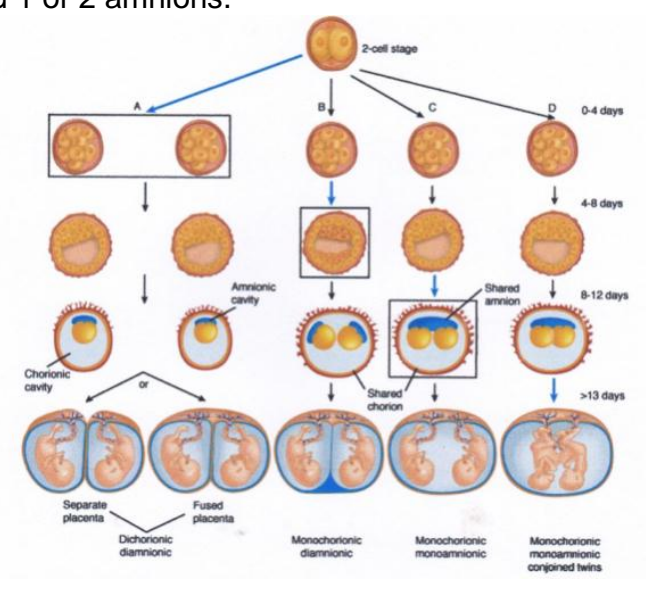

Figure 6. Mechanism of monozygotic twinning. Black boxing and blue arrows in columns $A, B$, and $C$ indicates timing of division. A. At 0 to 4 days postfertilization, an early conceptus may divide into two. Division at this early stage creates two chorions and two amnions (dichorionic, diamnionic). Placentas may be separate or fused. B. Division between 4 to 8 days leads to formation of a blastocyst with two separate embryoblasts (inner cell masses). Each embryoblast will form its own amnion within a shared chorion (monochorionic, diamnionic). C. Between 8 and 12 days, the amnion and amnionic cavity form above the germinal disc. Embryonic division leads to two embryos with a shared amnion and shared chorion (monochorionic, monoamnionic). D. Differing theories explain conjoined twin development. One describes an incomplete splitting of one embryo into two. The other describes fusion of a portion of one embryo from a monozygotic pair onto the other. ${ }^{3}$

The developmental mechanisms underlying monozygotic twinning are poorly understood. Minor trauma to the blastocyst during assisted reproductive technology (ART) may lead to the increased incidence of monozygotic twinning observed in pregnancies conceived in this manner.,

The outcome of the monozygotic twinning process depends on when division occurs. If zygotes divide within the first 72 hours after fertilization, two embryos, two amnions, and two chorions develop, and a diamnionic, dichorionic twin pregnancy evolves. Two distinct placentas or a single, fused placenta may develop. If division occurs between the fourth and eighth day, a diamnionic, monochorionic twin pregnancy results. By approximately 8 days after fertilization, the chorion and the amnion have already differentiated, and division results in two embryos within a common amnionic sac, that is, a monoamnionic, monochorionic twin pregnancy. Conjoined twins result if twinning is initiated later. It has long been accepted that monochorionicity incontrovertibly indicated monozygosity. Rarely, however, monochorionic twins may in fact be dizygotic (Souter and colleagues, Mechanisms for this are speculative, and zygotic manipulationsthat accompany ART have been implicated. . $^{3,8}$

Variations of pregnancy outcomes depend on how deep the relationship of the anastomose of the fetus blood vessel. It is related to the severity of the symptoms of TTTS.

Potential predictor for TTTS is the measurement of nuchal translucency (NT) at the early gestation, membrane fold between the ages of 15 and 17 weeks gestation, searching the arterio arterial anastomosis and umbilical cord insertion. Increased NT is a marker of chromosome anomaly, cardiac defects and genetic syndromes disorders. In monochorionic twin, an increased NT may indicate early cardiac dysfunction caused by hypervolemia congestion on recipient and is associated with subsequent development of TTTS. Clinical signs are more promising for predicting TTTS is the thickness of the membrane (membrane folding) intertwin at 15-17 weeks' gestation, contained in monochorionic twin. This sign is believed to be a reflection of oliguria and reduced amniotic fluid in fetal donor sac, and is associated with increased of development next TTTS. Another marker for the prediction of TTTS is no arterioarterial anastomosis. Arterioarterial anastomosis can be detected by color flow mapping and pulsed Doppler since 12 weeks pregnancy.

The presence or absence of reversed enddiastolic flow in the donor umbilical artery, abnormal recipient pulsation band venous system and the absence of arterio arterial anastomosis was identified freely to predict poor outcome. Staging system based on the findings of ultrasonography and fetal outcomes (Figure 2.) include: Stage $I$ is polyhydramnion (maximum vertical pocket $\geq 8 \mathrm{~cm}$ ) oligohydramnion (maximum vertical pocket $<2 \mathrm{~cm}$ ) with donor fetal bladder is still visible. Instage II, the donor fetal bladder to be empty (stuck twin). Progression to stage III occurs with severe abnormal Doppler results: absent or reversed end-diastolic flow umbilical artery Doppler fetal donor or sign of abnormal veins on recipient, such as reverse flow in the ductus venosus or pulsatile umbilical venous flow. Stage IV means fetal hydrops, and at the end of stage $V$ corresponding to the death of one or both of the twins. The purpose of this staging system is a valuable step In the standard approach to TTTS and to prove the usefulness of counseling and individualization therapy. $3,5,9$

The Quintero Stagging of Twin to Twin Transfussion syndom. $^{5}$ 
Table1. Quintero Staging System of TTTS ${ }^{5}$

\begin{tabular}{|c|c|c|}
\hline Stage & $\begin{array}{l}\text { Ultrasound } \\
\text { Parameter }\end{array}$ & $\begin{array}{l}\text { Categorical } \\
\text { Criteria }\end{array}$ \\
\hline I & $\begin{array}{l}\text { MVP(Maximal } \\
\text { Ventricle } \\
\text { Pocket )of } \\
\text { Amniotic Fluid } \\
\text { Index }\end{array}$ & $\begin{array}{l}\text { MVP }<2 \mathrm{~cm} \text { in donor sac, } \\
M V P>8 \mathrm{~cm} \text { in recipient sac }\end{array}$ \\
\hline II & Fetal Bladder & $\begin{array}{l}\text { Non Visualization of fetal } \\
\text { bladder in donor twin over } \\
60 \text { minute of observation }\end{array}$ \\
\hline III & $\begin{array}{l}\text { Umbilical } \\
\text { Artery, ductus } \\
\text { venosus, } \\
\text { Umbilical vein } \\
\text { doppler } \\
\text { waveforms }\end{array}$ & $\begin{array}{l}\text { Absent or reverse artery } \\
\text { umbilical } \\
\text { flow,revese ductus venosus, } \\
\text { a wave flow pulsatile } \\
\text { umbilical vein flow }\end{array}$ \\
\hline IV & Fetal Hydrops & $\begin{array}{l}\text { Fetal hydrops in one or both } \\
\text { twis }\end{array}$ \\
\hline $\mathrm{V}$ & $\begin{array}{l}\text { Absent fetal } \\
\text { cardiac Activity }\end{array}$ & $\begin{array}{l}\text { Fetal demise in one or both } \\
\text { twin }\end{array}$ \\
\hline
\end{tabular}

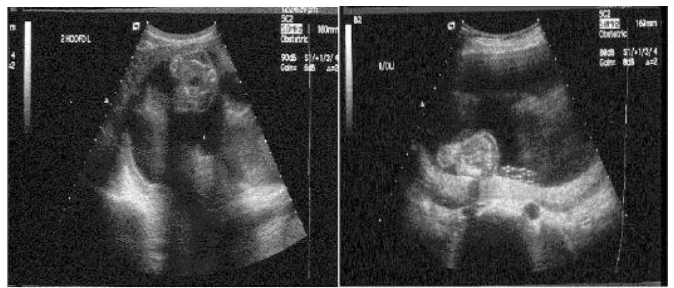

Stage I

Stage II

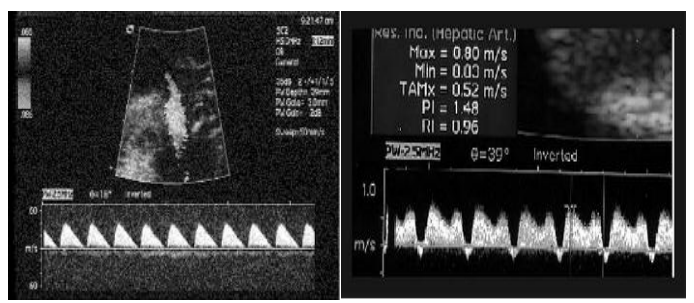

Absent end diastolic end Reversed a-wave ductus venosus

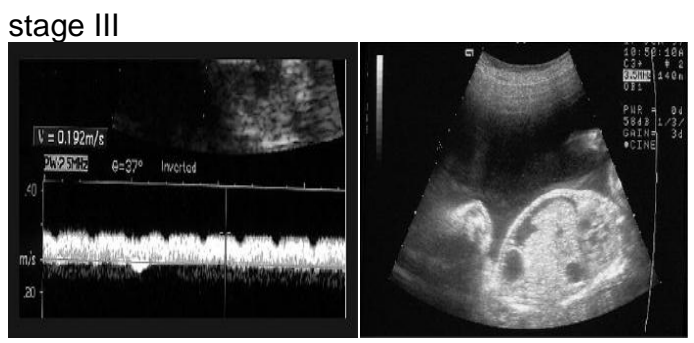

Vein Pulsation Stage IV

Figure 2. Ultrasonography finding in TTTS ${ }^{5}$

Stage I, polyhydramnion (maximum vertical pocket $\geq 8 \mathrm{~cm}$ ) oligohydramnion (maximum verticalpocket $<2 \mathrm{~cm}$ ) with donor fetal bladder is still visible; Stage II, Stuck twin with an empty bladder; Stage III, abnormal Doppler measurements (absent or reverse umbilical artery end diastolic flow, or reverse blood flow ductus venosus, or pulsatile venous blood flow); stage IV, fetal hydrops; Stage V (not shown) death of one or both twins. ${ }^{4,5,8}$

Mortality of untreated TTTS more than $80 \%$. Three common treatments for TTTS at mid trimester are amnio reduction, fetoscopic laser occlusion of the vessels chorioagiopagus (floc) of vascular anastomoses and septostomy. Serial Amnio reduction can control the volume of amniotic fluid. There is variability in drainage engineering, especially the amount of fluid drainage; fast or slow drainage. Denbow dkk made aggressive Amnio drainage with 1 literat the AFI increased every $10 \mathrm{~cm}$, to AFI less than $25 \mathrm{~cm}$. Based on the data, amnio reduction only effective in cases of moderate TTTS, with one of the three treatment failure cases and more than half of the patients who treated are still death, one or even both fetuses. Another therapy was fetoscopic laser occlusion of the vessels chorioangiopagus (Floc) with Coagulated all locked vascular anastomosis through the fetoscopy. $3,9,10$

In first case, the criteria for the diagnosis of TTTS is monochorionic placenta, polyhydramnios and distended bladder in the recipient fetus and severe oligohydramnion or fetal donor anhidramnion, it seen in the presence of a very small bladder or empty and stuck twin. According to The Quintero staging, the first case includes in stage II of TTTS with Polyhydramnion in the recipient fetus and severe oligohidramnion and stuck twin in donor.

In the Second case the diagnosis of TTTS Postpartum enforced by the presence of discordance Twin, same gender, monochorionic, and differences in hemoglobin greater than $5 \mathrm{~g} / \mathrm{dlw}$ ith anemia in smaller infants.

The differences in both cases are based on gestational age and fetal outcomes. These variations were determined by the severity of relationship between anastomose of the blood vessels. Its also related to the severity of the symptoms of TTTS.

TTTS is cause ddue to an unidirectional deep arteriovenous (AV) anastomoses with the superficial shortcomings. The superficial anastomosisis responsible for acute transfusion complications that can lead to IUFD one of fetuses. This evidence increases the likelihood of the risk of monochorionic fetus depends on the type and size of vascular flow anastomoses. Hipovolemia, oliguria and oligohydramnion occurs in the donor fetus, occurring phenomenon 'stuck twin'. Hypervolemia, polyuria and polyhydramnion occurs in the fetus recipient, and often lead to excess circulating volume and hydrops. ${ }^{3}$

Ultrasonography diagnostic of these syndromes are the single placental mass and the absence of the lambda sign or look alikes " $T$ sign" at the end of first trimester, and oligohydramnion or anhidramnion of the donor twin (often in the absence of the bladder) and hydramnion and an enlarged recipient bladder at the second trimester. May also be discordant between fetal growth or hydropsin one or both fetuses. ${ }^{5-7}$

\section{Conclusion}

TTTS is caused due to unidirectional deep arteriovenous (AV) anastomoses with the superficial shortcomings. Hypovolemia, oliguria and oligohydramnion occurs in the donor fetus, occurring 
phenomenon 'stuck twin'. Hypervolemia, polyuria and polyhydramnios occurs in the recipient fetus, and often lead to excess circulating volume and hydrops. If the syndrome is not treated, the survival ranges between $4 \%$ to $75 \%$.

\section{Literature}

1. Caroline F, Mark D, Khalid S. Contemporary treatments for twin-twin transfusion syndrom. American Journal of Obstetric and Gynecology. 2005; 105:1469-77

2. Liesbeth L, Schoubroecka DV, Grataco E, Wittersa I, Timmermana D, Depresta J. Monochorionic diamniotic twins: complications and management options. American Journal of Obstetrics and Gynecology. 2015:177-94.

3. Twin to Twin Transfusion Syndrome [editorial].BMJ. 2007; 316: 1581-6.

4. Wibowo B, Hanafiah MJ. Kehamilan kembar. Dalam: Sarwono P, editor. Ilmu Kebidanan. Jakarta: Yayasan Bina Pustaka; 1999. hlm. 385-97.

5. Rekha B, Ling $Y$, Shaheen A, Stuart W. Outcome of twin pregnancies complicated by single intrauterine death in relation to vascular anatomy of the monochorionic placenta. American Journal of Obstetrics and Gynecology.1999; 14(8): 2124-30.

6. Romaine R, Masami Y, Yves V. Selective feticide in complicated monochorionic twin pregnancies using ultrasound guided bipolar cordcoagulation. BJOG. 2005; 112(10).134448.

7. Cunningham FG.. Williams Obstetrics. Multifetal Pregnancy. Edisi ke-23. New York Mc Graw Hill. 2010.hlm.765-809

8. Dev K, Menin. A retrospective study of the accuracy of sonographic chorionicity determination in twin pregnancies. Australian Journal of Obstetrics. 2006; 3(8): 259-61.

9. Vicki N, Zvi L, Baram P, Israel S, Simon D, Gonen O. Dizygotic twin pregnancy discordant. J Ultrasound Med. 2007:97(103). 4278-97.

10. Lopriore E, Sueters M, Johanna MM, Klumper F, Oepkes D, Frank PH, et al. Twin pregnancies with two separate placental masses can still be monochorionic and have vascular anastomoses. American Journal of Obstetrics and Gynecology. 2006; 194: 8048. 